\title{
Penerapan Product Knowledge dan Strategi UpSelling Pada Chandra Tech Palembang
}

\author{
Fitri Purwaningtias*) \\ Jurusan Sistem Informasi, Fakultas Ilmu Komputer, Universitas Bina Darma, Palembang \\ Jln. Jendral Ahmad Yani No.3 Plaju, Kota Palembang, 30264, Indonesia \\ email: fitri.purwaningtias@binadarma.ac.id \\ Received: 9 Maret 2018; Revised: 11 Mei 2018; Accepted: 13 Mei 2018 \\ Copyright @2018 Politeknik Harapan Bersama Tegal. All rights reserved
}

\begin{abstract}
Chandra Tech store is a store that sells computer along with other computer accessories. In the Chandra store sales system is still having difficulties in searching for existing products and difficulties in finding information on goods products in the store and information specifications of goods to be purchased and still lack of public knowledge about the existence of this Chandra store. To overcome this problem then the application of product knowledge is suitable for this research is to provide information about the product to be sold with detail of goods, and recommends an up selling strategy in sales by explaining the most expensive products, product searches, and about purchases and payments as well as about purchases and payments that can be done so that customers become more interested in purchasing the most expensive products. The research is website for product selling with the application of product knowledge and sales up selling strategy with a descriptif method for research and system development method is OOAD (Object Oriented Analysis and Design) starting from requirements, analysis, design, implementation and testing. With this website can help customers in facilitating the purchase of products in this store and can help the store to promote products sold and can raise services to customers through online sales.
\end{abstract}

Abstrak - Chandra Tech merupakan toko yang menjual komputer beserta aksesoris komputer lainnya. Sistem penjualan pada toko Chandra masih mengalami kesulitan dalam pencarian produk yang ada dan kesulitan dalam mencari informasi produk barang dan informasi spesifikasi barang yang akan dibeli serta masih kurangnya pengetahuan masyarakat tentang keberadaan toko Chandra ini. Untuk mengatasi permasalahan ini maka penerapan product knowledge sangat cocok untuk penelitian ini yaitu memberikan informasi tentang produk yang akan dijual dengan detail barang, serta merekomendasikan strategi up selling dalam penjualan dengan memberi penjelasan produk harga termahal, pencarian produk, serta tentang pembelian dan pembayaran yang bisa dilakukan sehingga customer menjadi lebih tertarik untuk pembelian produk termahal. Penelitian ini menghasilkan website penjualan produk secara online dengan penerapan product knowledge dan strategi penjualan up selling dengan metode penelitian yaitu metode deskriptif dan metode pengembangan sistem yaitu OOAD (Object Oriented Analysis and Design) dimulai dari requirements, analisis, design, Dengan adanya website ini bisa membantu pelanggan dalam memudahkan pembelian produk di toko ini dan bisa membantu pihak toko untuk mempromosikan produk

*) Corresponding author: Fitri Purwaningtias

Email: fitri.purwaningtias@binadarma.ac.id yang dijual dan bisa menaikkan layanan pada pelanggan melalui penjualan online.

Kata Kunci - Website, Up Selling, Product Knowledge

\section{PENDAHULUAN}

Toko Chandra Tech, sebuah perusahaan yang bergerak di bidang penjualan berbagai perangkat komputer dan aksesoris komputer dengan berbagai tipe, merk dan harga. Pada toko chandra ini penjualan hanya dilakukan dengan customer datang langsung ke toko untuk bisa melihat produk yang dijual. Sehingga terkadang customer yang datang kadang masih bingung untuk menentukan produk yang akan dibeli karena spesifikasinya yang tidak diketahui kemudian customer malah bertanya dengan karyawan toko, dengan bertanya pada karyawan toko menjadi kurang efektifnya penjualan karena membutuhkan alur penjualan yang lama dan apa yang dilakukan antara customer dan karyawan toko semakin banyak pertanyaan yang customer tanyakan dan pelayanan karyawan toko nantinya akan menjadi berkurang dikarenakan karyawan toko juga kurang mengetahui informasi produk yang ada dan malas melayani. Setelah customer menyetujui produk apa yang akan dibeli maka karyawan toko akan mengecek stok barang pada pemilik toko untuk mengetahui stok barang ada atau tidak sehingga terasa kurang efisiensi karena tidak ada sistem yang digunakan. Permasalahan lainnya yaitu toko chandra tech ini belum terlalu terkenal sehingga pemasarannya belum bisa menjangkau di luar Palembang sehingga toko ini masih perlu melakukan promosi toko untuk bisa menaikkan penjualan toko .

Dari berbagai permasalahan yang ada dan apabila tidak di atasi maka Chandra Tech tidak akan mampu bersaing di pangsa pasar karena tidak mengikuti perkembangan dari teknologi saat ini, seperti yang telah dilakukan oleh pihak toko lain yang telah berkembang bahkan bisa jadi gulung tikar. Penggunaan website untuk toko online bisa sebagai solusi yang digunakan untuk membuat perkembangan bisnis pada toko Chandra Tech dikarenakan website berupa kumpulan halaman yang diawali dengan halaman muka berisikan informasi, iklan dan program aplikasi [1]. Pada website tersebut akan diterapkan product knowledge dan strategi pemasaran up selling di dalamnya. 
Poduct Knowledge yaitu cakupan seluruh informasi akurat yang disimpan dalam memori konsumen yang sama baiknya dengan persepsinya tehadap pengetahuan produk [2]. Ada tiga jenis pengetahuan produk berupa pengetahuan tentang atibut produk atau karakteristik produk, pengetahuan dari manfaat produk dan pengetahuan tentang kepuasan yang diberikan produk bagi customer [3]. Untuk mengukur pengetahuan produk dengan (1) produk sebagai paket atribut; (2) produk sebagai paket manfaat; dan (3) produk sebagai nilai yang memuaskan [4]. Karena untuk terjadinya penjualan dibutuhkan pengetahuan customer tentang produk yang akan dibeli. Dimana customer yaitu individu atau kelompok yang membeli produk atau jasa dari keputusan mereka atas apa yang mereka butuhkan baik dilihat dari manfaat dan harga produk atau jasa tersebut [5]. Dengan adanya website ini customer bisa mencari informasi mengenai detail dari produk yang akan dibeli dan bisa melakukan transaksi penjualan tanpa harus datang ke toko Chandra.

Selain itu diharapkan juga dengan website ini bisa memperluas jangkauan penjualan dan sebagai media promosi yang baik. Sedangkan Strategi Up Selling yaitu program untuk penjualan yang digunakan untuk menawarkan produk yang memiliki produk serupa tapi dengan nilai yang lebih tinggi dari produk yang dipilih [6]. Jadi inti kegunaan dari up selling untuk membujuk pelanggan agar membeli lebih dari pada yang dia butuhkan atau niatkan sebelumnya [7]. Pembuatan website penjualan online ini dilakukan untuk meningkatkan layanan kepada customer tentang informasi produk dan mendapatkan pelanggan baru dari daerah lain serta bisa menaikkan profit bagi toko.

Dari uraian permasalahan yang ada maka penelitian ini membuat sebuah website untuk penjualan produk pada Toko Chandra Tech berbasis online yang mana pada website ini akan diterapkan product knowledge dan strategi up selling didalamnya guna membuat customer lebih tertarik untuk membeli produk yang dijual toko tersebut. Dengan adanya website online ini juga bisa mendukung kegiatan bisnis yang dilakukan oleh toko Chandra Tech Palembang dengan efektif dan mempemudah jangkauan penjualan yang dilakukan serta bisa meningkatkan kualitas pelayanan bagi customer.

\section{PENELITIAN YANG TERKAIT}

Perusahaan pada umumnya harus berinteraksi dan berhubungan dengan pihak lain maka adanya konsep customer relationship marketing (CRM). Di dalam CRM ini salah satunya metode yang digunakan yaitu metode up selling. Up selling adalah gagasan untuk meng-upgrade produk yang pelanggan pesan untuk mendapatkan layanan tambahan. Cara untuk mengaplikasi Up Selling yaitu dengan mengambil data barang yang harga jualnya lebih tinggi dari barang yang sedang dilihat. Mengurutkan dari hari harga termurah sampai termahal serta menampilkan barang dari harga termurah sampai termahal [8]. Selanjutnya pada kajian lain, up selling digunakan dengan metode product knowledge.

Untuk mengkombinasikan dengan penerimaan informasi product knowledge dan metode dari rekomendasi up selling maka harus mengetahui penjelasan yaitu bahwa product knowledge, dengan memberi pengetahuan tentang atribut dari produk yang dimiliki baik itu ciri melalui abstrak dan pengetahuan ciri nyata serta komponen atributnya. Sedangkan up selling adalah upaya meningkatkan loyalitas pelanggan dan meningkatkan penjualan dengan mengarahkan customer untuk membeli produk yang lebih mahal. Sehingga website toko online yang dibuat memberikan penjelasan atas spesifikasi produk yang dijual [9]. Selanjutnya kajian lain bahwa metode Up Selling dikombinasikan dengan sosial media untuk meningkatkan penjualan [10]. Up selling juga bisa digunakan sebagai metode promosi dengan menerapkan metode up selling menjadi 5 yaitu menawarkan produk secara mendalam, kemudian membaca karakteristik pelanggan, memberikan kesempatan pelanggan untuk memilih, memberikan penawaran yang wajar pada pelanggan serta memberi nilai tambah pada produk yang akan ditawarkan [11].

Berdasarkan beberapa kutipan diatas bahwa Toko Candra Tech memerlukan website toko online sebagai sarana penjualan saat ini dengan menerapkan product knowledge dan strategi up selling didalamnya guna bisa megikuti persaingan bisnis saat ini yang telah menggunakan teknologi didalam bisnisnya.

\section{METODE PENELITIAN}

Peneliti melakukan penelitian ini menggunakan metode OOAD dimana OOAD adlah metode yang digunakan untuk membuat benda-benda disebut pelaku dan yang mewakili pengguna manusia akan berinteraksi dengan sistem [12]. Berikut tahapan yang digunakan terdapat pada Gbr 1.

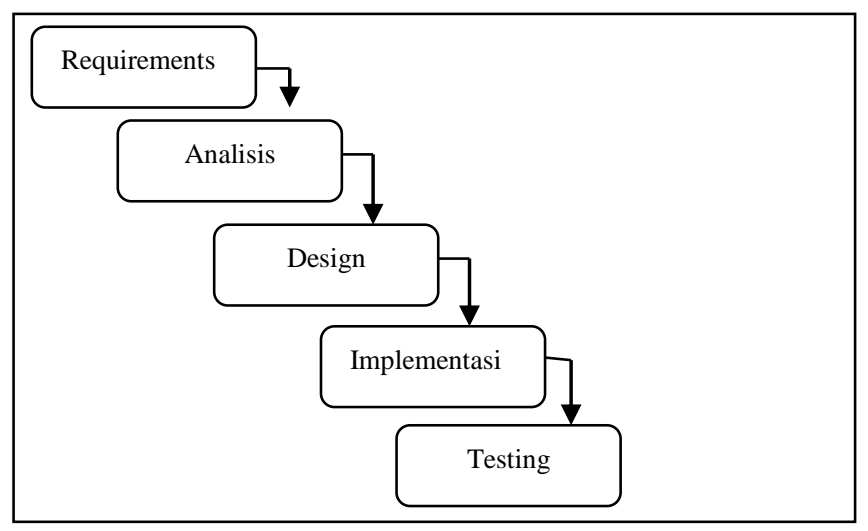

Gbr 1. Tahapan OOAD

Dari Gbr.1 bisa diketahui apa yang dilakukan pada penelitian ini dari tiap tahapannya yaitu:

1) Tahap Requirements (Persyaratan)

Pada tahapan ini peneliti menentukan persyaratanpersyaratan yang harus dilakukan ataupun tidak harus dilakukan oleh sistem. Cakupan persyaratan terdiri dari:

a) Aktor dan Kasus Penggunaan: dalam penelitian ini aktor pengguna sistem dalam website ini yaitu customer dan admin penjualan dengan memiliki fungsi masing-masing pengelolaan didalam sistem.

b) Persyaratan Fungsional: yaitu menentukan persyaratan layanan sistem yang disediakan seperti apa saja yang bisa dilakukan oleh customer dan admin penjualan didalam sistem ini dan layanan apa saja yang ditawarkan didalam sistem yang dibuat.

c) Persyaratan Non Fungsional: maksudnya untuk menentukan batasan atau fungsi yang ditawarkan oleh sistem seperti bahwa tidak semua orang yang masuk ke dalam 
website bisa melakukan pembelian tanpa melakukan login terlebih dahulu dan menjadi member dalam sistem.

\section{2) Tahap Analysis}

Selanjutnya setelah penentuan requirements maka peneliti menganalisis permasalahan yang dihadapi pada Chandra Tech ini bahwa Chandra Tech membutuhkan sebuah website toko online dengan menggunakan metode Up Selling didalamnya sebagai rekomendasi produk dan penerapan product knowledge untuk pengetahuan customer terhadap produk yang ada di toko dengan spesifikasi produk sehingga customer bisa mengetahui spesifikasi produk yang akan dibeli.

\section{3) Tahap Design (Perancangan)}

Setelah analisis maka dilakukan perancangan untuk pembuata rancangan proses menggunakan UML yaitu bahasa pemodelan untuk sistem yang berparadigma berorientasi objek [13]. Didalam UML yang digunakan yaitu salah satunya Use Case Diagram, rancangan database yaitu sekumpulan data store yang tersimpan dalam magnetic disk, official disk, magnetic drum atau media penyimpanan sekunder lainnya [14], digunakan untuk gambaran dari pembuatan database sebagai tempat penyimpanan data dari sistem yang dibuat dengan nama db_chandra dan rancangan program yang akan dibuat.

\section{4) Tahap Implementasi}

Kemudian peneliti melakukan pengcodingan dari website toko online ini menggunakan bahasa pemrograman PHP.

\section{5) Tahap Testing}

Setelah selesai pembuatan website ini dengan menerapkan metode product knowledge dan metode up selling kemudian dilakukanlah pengujian sistem menggunakan black box yaitu pengujian perangkat lunak dari segi fungsional tanpa menguji desain dan kode program [15].

\section{HASIL DAN PEMBAHASAN}

Hasil dari penelitian ini yaitu berupa website toko chandra tech dimana didalam website tersebut menggunakan product knowledge dan metode up selling. Website ini terdapat pemisahan layanan dari login antara admin dan customer sebagai user.

\section{A. Layanan Customer}

1) Halaman tampilan awal website

Pada gbr 2 adalah halaman tampilan awal website ketika customer membuka website toko chandra tech ini. Pada halaman awal website, customer bisa memilih berbagai kategori produk yang akan dibeli

\section{2) Halaman Member.}

Pada Gbr.3 menjelaskan tentang bagaimana customer tersebut untuk menjadi member di toko chandra tech. Halaman member juga berguna untuk customer menjadi member toko jika customer berminat untuk melakukan pembelian produk.

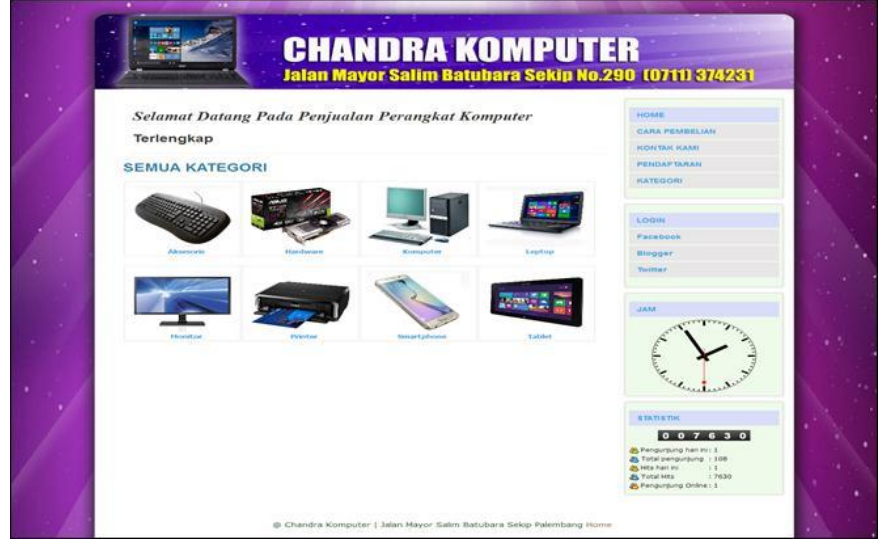

Gbr. 2 Halaman Awal Website

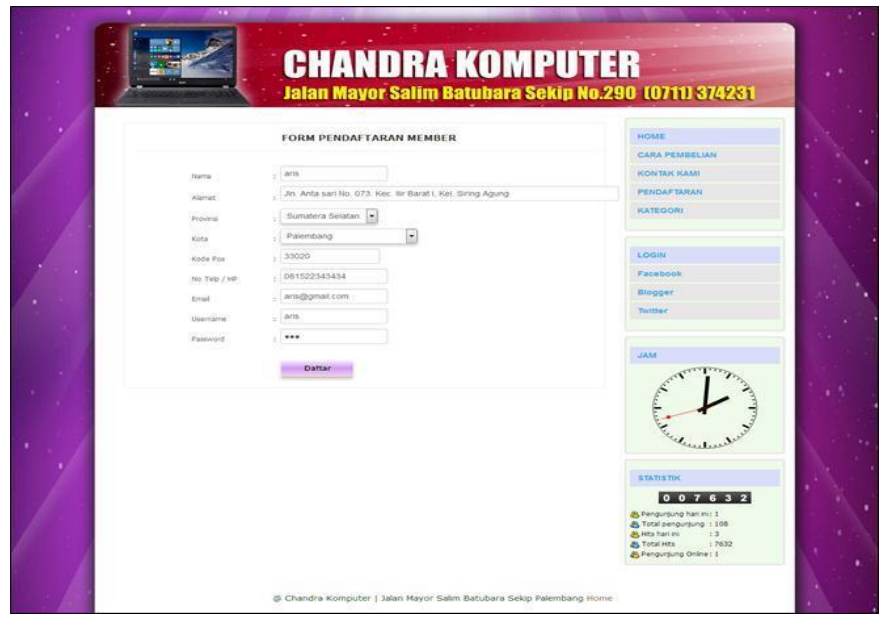

Gbr. 3 Halaman Member

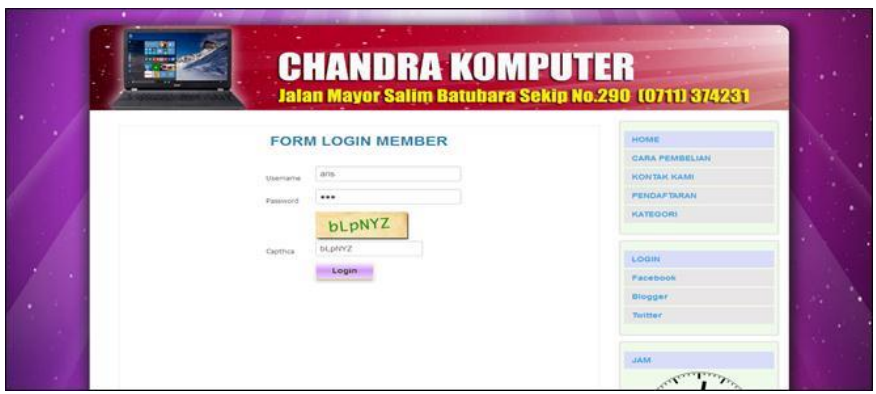

Gbr. 4 Halaman Login Costumer

\section{3) Login, berfungsi untuk login costumer}

Pada Gbr 4 menjelaskan bahwa untuk melakukan pembelian produk maka customer harus menjadi member. Setelah menjadi member maka transaksi pembelian bisa dilakukan oleh customer dengan melakukan login sebagai customer sesuai dengan data yang telah diisi pada form member. 
4) Halaman Daftar Barang

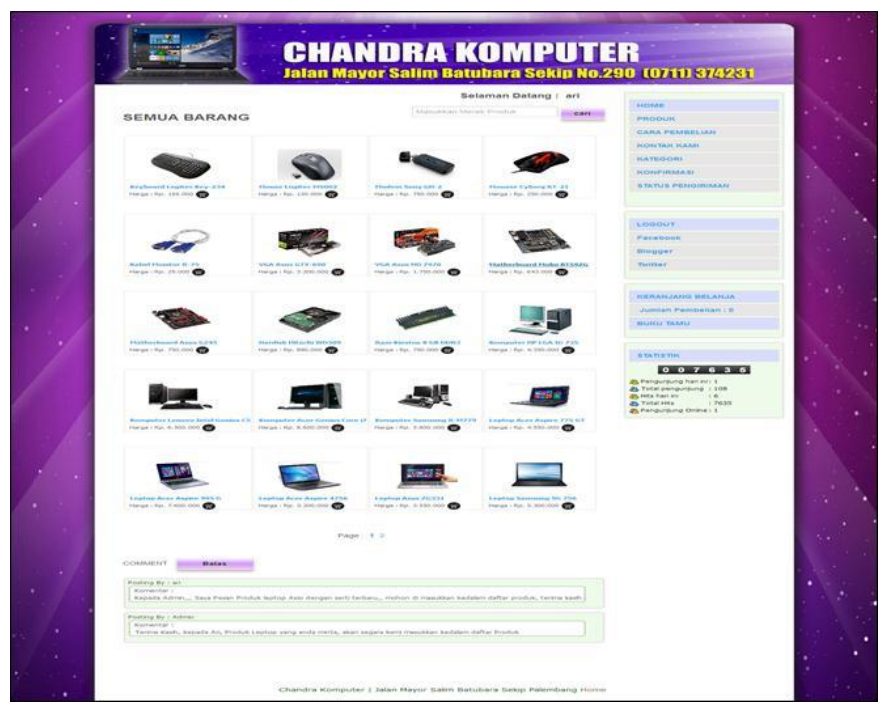

Gbr. 5 Halaman Daftar Produk

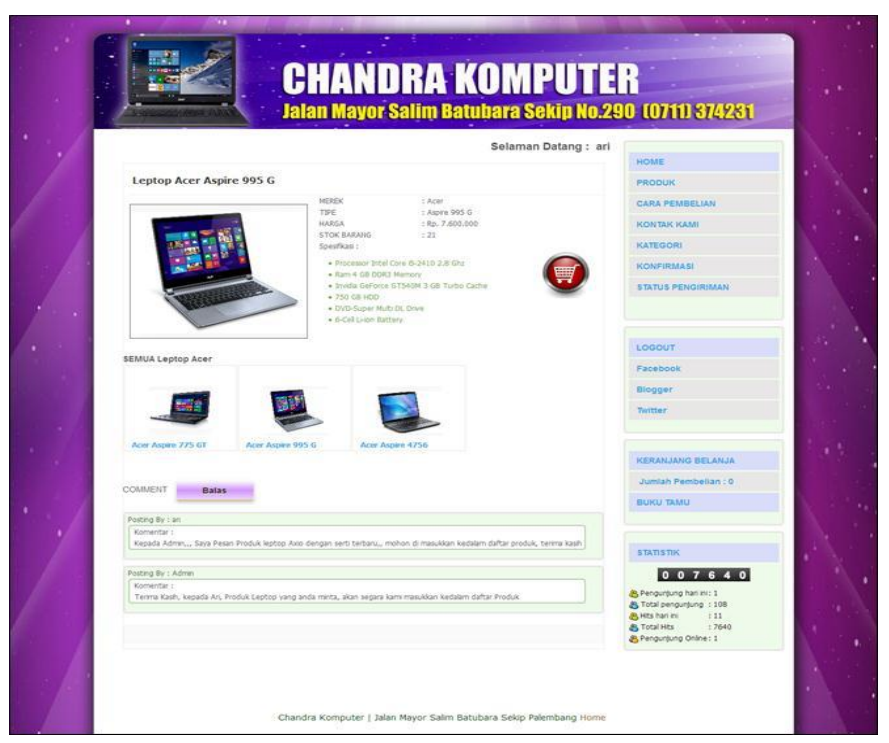

Gbr. 6 Halaman Detail Produk

Setelah login maka customer masuk ke halaman daftar produk yang diminati sesuai dengan kategori yang dipilih. Daftar produk ini berfungsi untuk customer masuk ke menu pembelanjaan dengan memilih produk yang diinginkan dan akan ditampilkan informasi rincian detail barang yang terdapat pada Gbr 6. Pada Gbr 6 ini terdapat metode Product Knowledge yaitu memberikan informasi secara detail tentang produk yang akan dibeli.

\section{5) Halaman Penawaran Up Selling}

Pada gbr 7 terdapat halaman website yang menerapkan menggunakan up selling. Ketika customer mengklik tombol keranjang belanja pada halaman detail produk maka sistem menampilkan penawaran berdasar kategori produk yang sama dengan proses pengambilan data produk terlaris dengan penjualan tertinggi serta harga produk yang tinggi dengan kualitas terbaik dari barang sebelumnya.

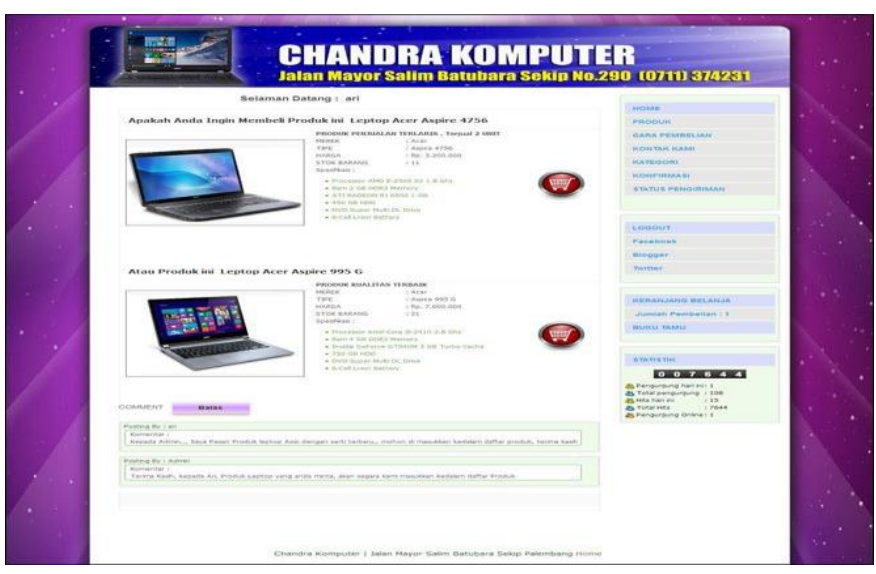

Gbr. 7 Halaman Penawaran Up Selling

6) Halaman Rincian Pembelian yang telah dilakukan Customer

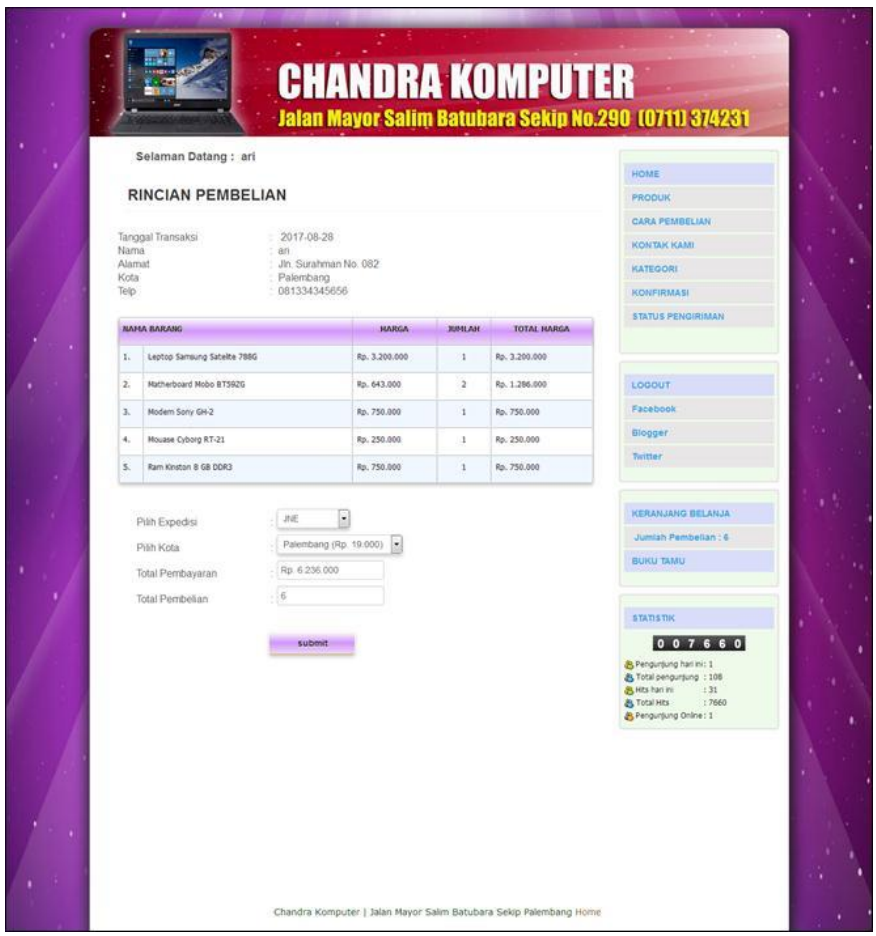

Gbr. 8 Halaman Rincian Pembelian

Gbr 8 menjelaskan tentang rincian pembelian yang telah dilakukan oleh customer untuk bisa dilakukan pembayaran.

\section{7) Halaman Konfirmasi Pembayaran}

Pada Gbr 9 menjelaskan jika customer telah melakukan pembayaran sehingga customer diharuskan untuk mengupload bukti transfer sebagai bukti telah melakukan pembayaran dan barang siap untuk dikirim. 


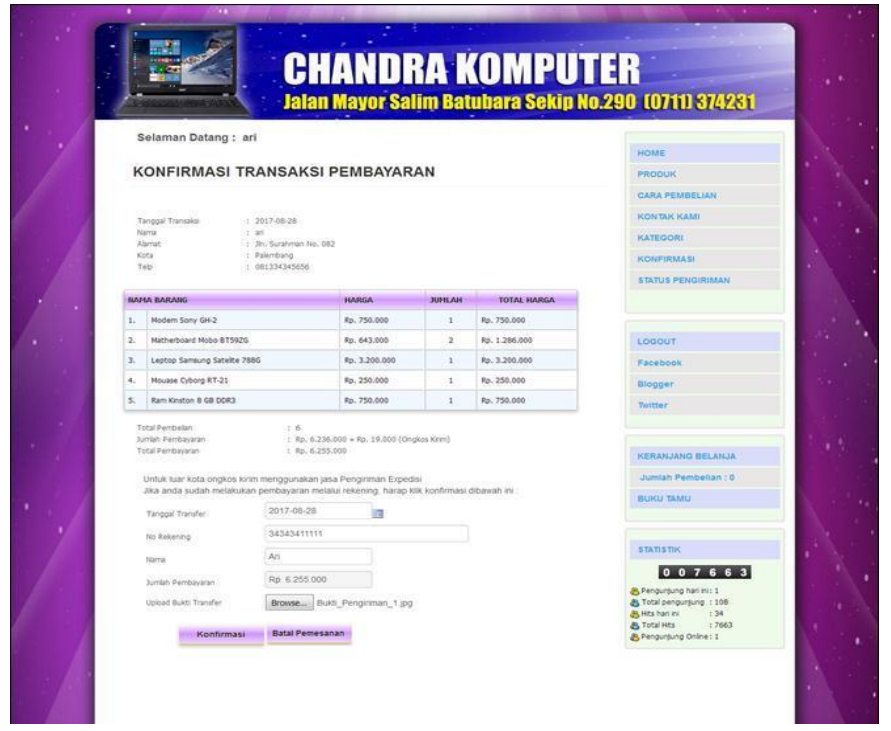

\section{B. Layanan Admin}

1) Login Admin

Gbr.11 menjelaskan tentang halaman login admin untuk bisa masuk ke sistem.

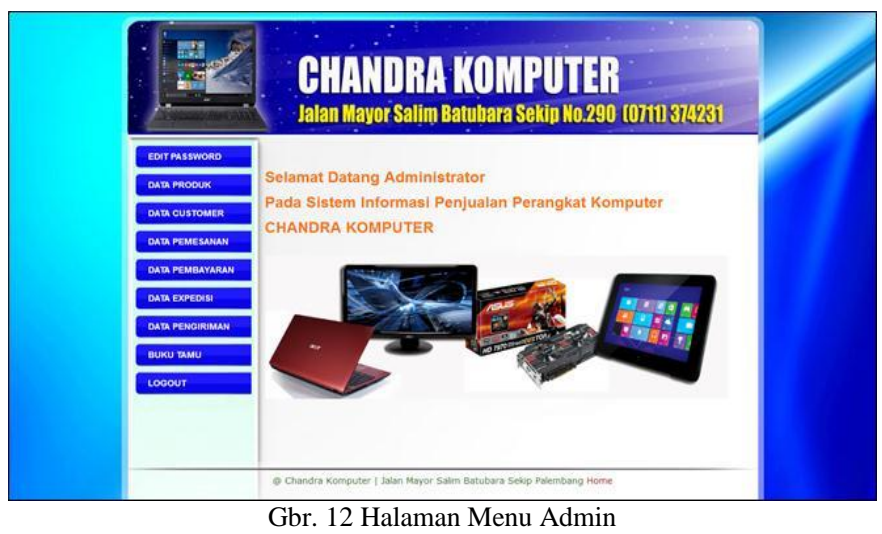

Gbr. 9 Halaman Konfirmasi Pembayaran
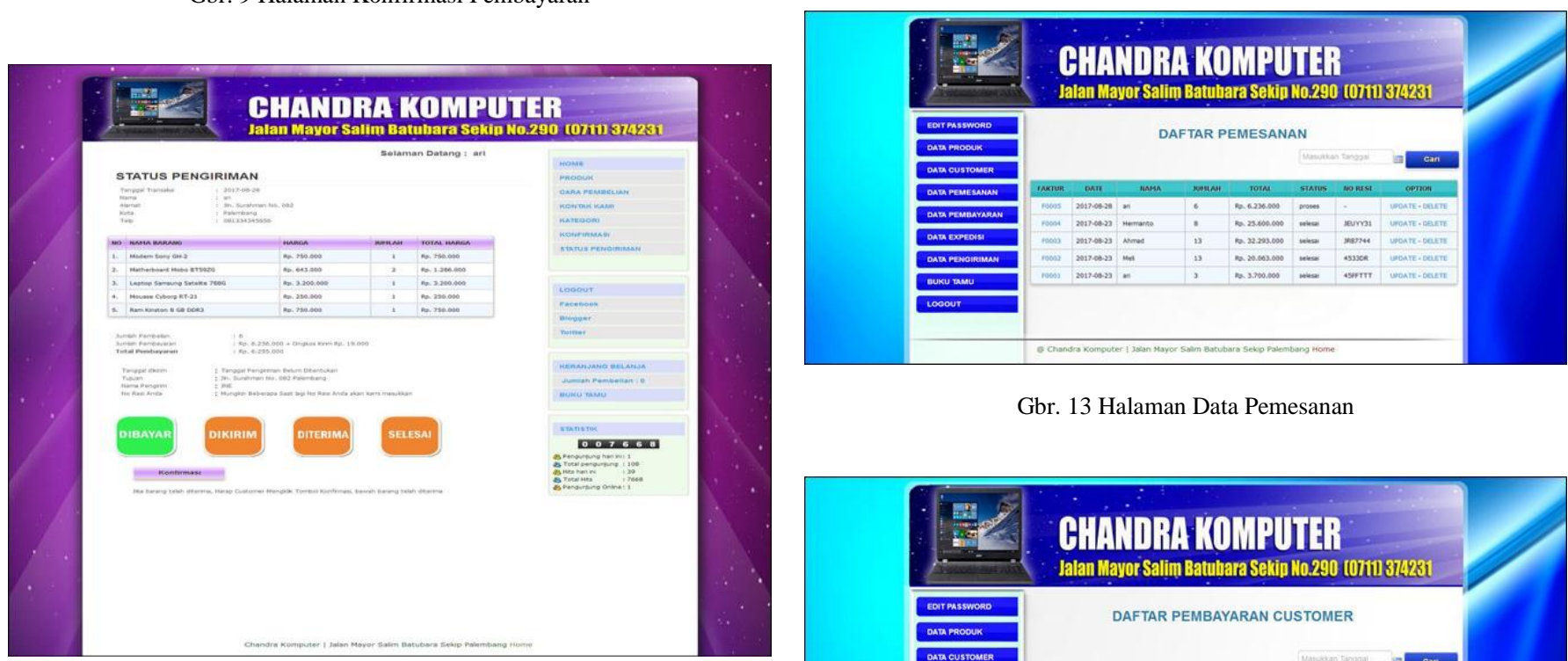

Gbr. 13 Halaman Data Pemesanan

Gbr. 10 Halaman Status Pengiriman
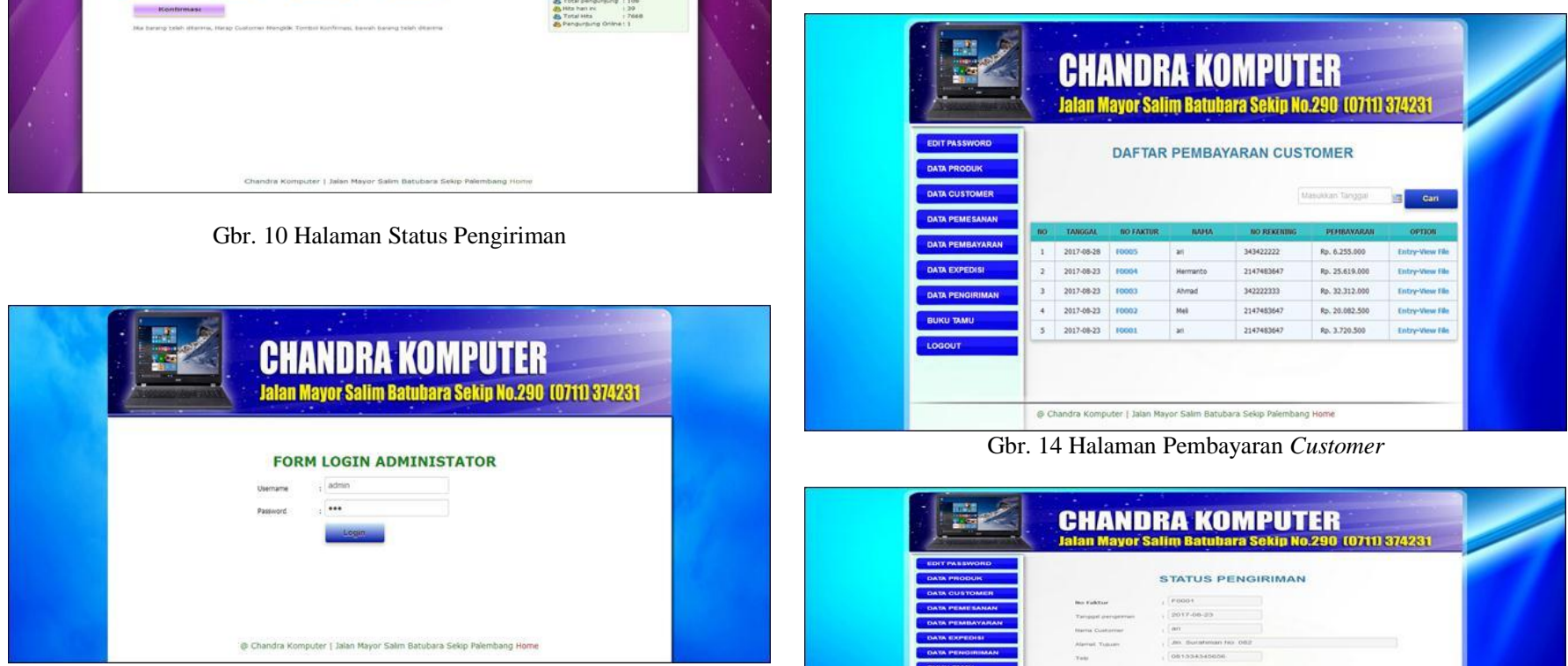

Gbr. 14 Halaman Pembayaran Customer

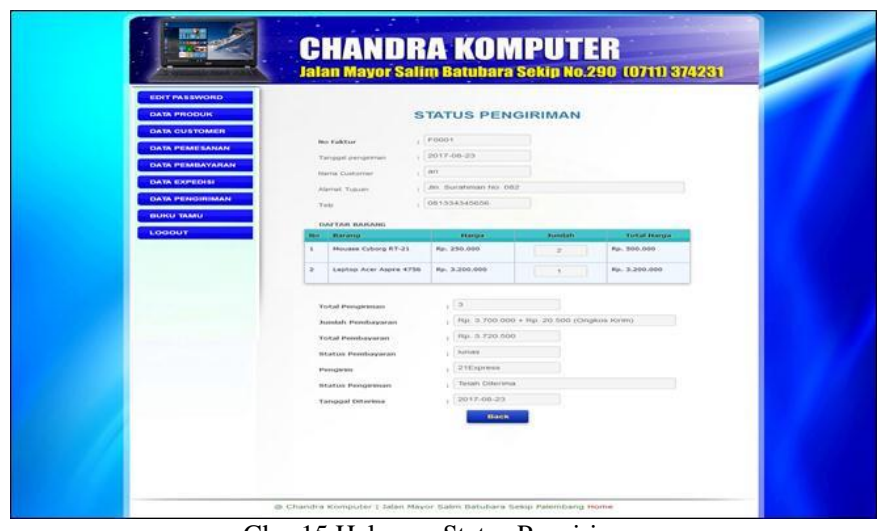

Gbr. 15 Halaman Status Pengiriman

Gbr. 11 Halaman Login Admin

\section{8) Halaman Status Pengiriman}

Pada Gbr 10 tentang status pengiriman yang telah dilakukan oleh pihak toko untuk berguna untuk customer bisa melihat pengiriman produk yang dibeli telah ada dimana lokasinya. 


\section{2) Halaman Menu Admin}

Pada Gbr.12 menjelaskan akses admin apa saja yang bisa dilakukan di website baik untuk memanipulasi data customer, data produk barang, data pembelian, data pembayaran dan data pengiriman barang pada customer.

\section{3) Halaman Data Pemesanan}

Halaman ini untuk admin melihat data pemesanan yang telah dilakukan oleh customer. Selanjutnya admin bisa melihat data pemesanan yang telah dilakukan customer seperti pada Gbr. 13.

\section{4) Halaman Pembayaran}

Berupa pembayaran yang telah dilakukan oleh customer. Pada Gbr 14 menjelaskan bahwa admin juga bisa mengakses data pembayaran yang telah dilakukan customer dan bisa melakukan konfirmasi customer yang telah melakukan pembayaran untuk barangnya siap dikirim.

\section{5) Halaman Status Pengiriman}

Pada gbr 15 form untuk status pengiriman, admin juga bisa untuk konfirmasi barang customer yang melakukan pembelian telah ada dimana statusnya dan customer bisa melihat pengiriman barang yang dilakukan sampai mana.

\section{Pengujian Sistem}

Pengujian pada website ini dengan menggunakan pengujian blackbox yang mana bagian-bagian yang diujikan bisa dilihat pada tabel I dan tabel II.

TABEL I

PENGUJIAN PADA LAYANAN CUSTOMER

\begin{tabular}{|l|c|c|}
\hline \multicolumn{1}{|c|}{ Komponen Uji } & Teknik Pengujian & Diterima \\
\hline Login & Pengujian/Blackbox & $\sqrt{ }$ \\
\hline Member & Pengujian/Blackbox & $\sqrt{ }$ \\
\hline Upload Bukti Bayar & Pengujian/Blackbox & $\sqrt{ }$ \\
\hline Status Pengiriman & Pengujian/Blackbox & $\sqrt{ }$ \\
\hline
\end{tabular}

TABEL II

PENGUJIAN PADA LAYANAN ADMIN

\begin{tabular}{|l|c|c|}
\hline \multicolumn{1}{|c|}{ Komponen Uji } & Teknik Pengujian & Diterima \\
\hline Login & Pengujian/Blackbox & $\sqrt{ }$ \\
\hline Member & Pengujian/Blackbox & $\sqrt{ }$ \\
\hline $\begin{array}{l}\text { Pembayaran belum } \\
\text { divalidasi }\end{array}$ & Pengujian/Blackbox & $\sqrt{ }$ \\
\hline $\begin{array}{l}\text { Pembayaran telah } \\
\text { divalidasi }\end{array}$ & Pengujian/Blackbox & $\sqrt{ }$ \\
\hline $\begin{array}{l}\text { Validasi status } \\
\text { pengiriman }\end{array}$ & Pengujian/Blackbox & $\sqrt{ }$ \\
\hline
\end{tabular}

Tabel I menjelaskan pengujian blackbox yang dilakukan akses sebagai customer dimana pengujiannya dilakukan pada login customer, member, upload bukti bayar dan status pengiriman barang bahwa setelah diuji ternyata tidak mengalami kesalahan dan bisa berfungsi sebagaimana mestinya.
Tabel II menjelaskan pengujian blackbox yang dilakukan akses sebagai admin dimana pengujiannya dilakukan pada login admin member, pembayaran belum divalidasi dan pembayaran telah divalidasi dan status pengiriman barang bahwa setelah diuji ternyata tidak mengalami kesalahan dan bisa berfungsi sebagaimana mestinya.

\section{KESIMPULAN}

Penelitian ini menghasilkan sebuah website pada toko Chandra tech dengan menerapkan metode product knowledge dan metode up selling yang bisa membantu pihak toko dan customer dalam proses transaksi jual beli produk yang ditawarkan dan memberi kemudahan dalam pemberian layanan produk dan sebagai sarana untuk promosi produk apa yang dijual oleh toko sehingga bisa meningkatkan profit perusahaan. Hanya saja pada website ini masih ada kekurangan yaitu masih perlu untuk dikembangkan kembali untuk bisa menjadi website yang lebih dinamis dan bisa lebih menarik lagi.

\section{DAFTAR PUSTAKA}

[1] P. Asropudin, Teknologi Informasi Komunikasi, Bandung: Titian Ilmu, 2013.

[2] A. Rao dan W. Sieben, "The Effect of Prior Knowledge on Price Acceptability and The Type of Information Examined," Journal of Consumer Research, pp. 256-270, 1992.

[3] J. P. Peter dan J. C. Olson, Perilaku Konsumen dan Strategi Pemasaran Edisi 8. Terjemahan, Jakarta: Erlangga, 2002.

[4] J. P. Peter dan J. C. Olson, Perilaku Konsumen dan Strategi Pemasaran Edisi 8. Terjemahan, Jakarta: Erlangga, 2008.

[5] P. Greenberg, Customer Relationship Management as the Speed of Light: Fourth Edition, McGraw-Hill, 2010.

[6] B. Tama, "Penerapan Strategi Penjualan Menggunakan Association Rules dalam Konteks CRM," Jurnal Generic, vol. 5 nomor 1, p. 37, 2010

[7] M. Cohen, Exploiting Response Models-Optimizing Cross-sell and Upsell Opportunities In Banking, Jakarta: Information Systems, 2013.

[8] R. V. Imbar dan D. Gunawan, “Aplikasi Penjualan Komputer dengan MEtode Crosselling dan Upselling dilengkapi Algoritma Greedy dalam Pengambilan Keputusan," Jurnal Sistem Infromasi, vol. 8 nomor 1, pp. 95-111, 2013

[9] R. A. Priyantina, A. P. Widodo dan T. Sutanto, "Rancang Bangun Website Toko Online dengan Penerapan Produk Knowledge dan Strategi Up Selling pada MC Store Surabaya," JSIKA, vol. 5 nomor 4, pp. 1-7, 2016

[10] M. Willybrodus, A. Sukmaaji dan T. Soebijono, "Re-Desain Website CV.Planktoon dengan Metode Up Selling dikombinasikan dengan Sosial MEdia untuk Peningkatan Penjualan," JAVA Journal of Electrical and Electronics Engineering, vol. 13 nomor 2, pp. 36-39, 2015 .

[11] H. A. Y. Ranius dan Hutrianto, "Penerapan Metode Up Selling Terhadap Sistem Informasi Penjualan pada Toko SETH Sport Berbasis Web," S1. Submitted for publication, 2016.

[12] S. B. Gary dan H. J. Rosenblatt, Systems Analysis and Design Nineth Edition, United States of America: Course Technology, 2012.

[13] A. Nugroho, Rekayasa Perangkat Lunak Menggunakan UML dan JAva, Yogyakarta: Graha Ilmu, 2010.

[14] A.-B. B. Ladjamudin, Analisis dan Desain Sistem Informasi, Yogyakarta: Graha Ilmu, 2013.

[15] A. Rosa dan M. Salahuddin, Modul Pembelajaran Rakayasa Perangkat Lunak (Terstruktur dan Berorientasi Objek), Bandung: Modula, 2011. 